\title{
Investigating characteristics of tsunami hazards for west coast of Aceh Besar district, Indonesia
}

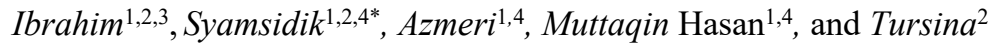

${ }^{\text {I}}$ Doctoral Program, School of Engineering, Universitas Syiah Kuala (USK), Jl. Syech Abdurrauf No. 7, Darussalam, Banda Aceh, 23111, Indonesia

${ }^{2}$ Tsunami and Disaster Mitigation Research Center (TDMRC), Universitas Syiah Kuala, Jl. Prof. Dr. Ibrahim Hasan, Banda Aceh, 23233, Indonesia

${ }^{3}$ Civil Engineering Department, Politeknik Negeri Lhokseumawe, J1. Banda Aceh-Medan, Km. 280,3, Lhokseumawe, 24301, Indonesia

${ }^{4}$ Dept. of Civil Engineering, Universitas Syiah Kuala, Jl. Syech Abdurrauf No. 7, Darussalam, Banda Aceh, 23111, Indonesia

\begin{abstract}
The seismic activities of a long section of the Sunda Plate revealed the vulnerability of the Indian Ocean to tsunami along the west coast of Sumatra, including on the west coast of Aceh Province. This megathrust caused the great tsunamigenic earthquake of 2004 and can be a possible candidate for rupture in the future and will affect or destroy everything, especially buildings along the coast. The west coast of Aceh Besar is one of the worst areas hit by tsunami waves and can cause tsunamis in the future. The objectives of this study are to determine the height, distance, and area of the tsunami inundation on the west coast of Aceh Besar District based on three earthquake magnitudes scenarios Mw 8.0, 8.5, and 9.2. The COMCOT (Cornell Multigrid Coupled Tsunami Model) tsunami model was used to obtain the height, area, and distance of the tsunami inundation. It was found that the largest tsunami inundation was caused by the tsunami generated by the magnitude Mw 9.2 earthquake. The maximum tsunami run up reached up to 20 meters with an inundation distance of $6 \mathrm{~km}$ from the coastline and a tsunami inundation area of $40 \mathrm{~km}^{2}$ distributed along the west coast of Aceh Besar District.
\end{abstract}

\section{Introduction}

The seismic activities along Sunda Plate revealed the vulnerability of the Indian Ocean to tsunami along the west coast of Sumatra. That includes the area along the west coast of Aceh Province. This megathrust is the source of the great tsunamigenic earthquakes of 2004. The tsunami in the area can still be a possible candidate for rupture in the future and will affect or destroy everything especially building along the coast. In addition to the Mw 9.1 - 9.32004 earthquake [1], other large earthquakes have also occurred along with the Sunda plate with a magnitude of Mw 7.7 to Mw 8.9 [2]. The return period of an earthquake with a magnitude of 7.5 to 9.3 is 55 to 500 years [3].

The earthquake and tsunami that struck Aceh in December 2004 are the worst natural disaster in living memory [4].The west coast area of Aceh Besar District, which is part of the west coast of Aceh, was one of the areas most severely hit. . This area was hit by a tsunami as high as 15 to 30 meters which destroyed many buildings and caused many casualties [5,6]. After 16 years of the tsunami, this area was rebuilt with various uses such as residential areas, tourism, industries, and public facilities. The population rate in this area reaches $11.05 \%$ [7]. Generally, this area is located or

${ }^{*}$ Corresponding author: syamsidik@tdmrc.org concentrated on the coast. With the history of previous earthquake events and the potential for tsunami events in the future, research is needed to investigate the potential hazards of tsunami waves in the context of tsunami wave mitigation.

Several studies have been conducted in this area. Research on tsunami estimated times of arrival (ETAs) for cities in Aceh has been done [8]. They found the ETAs for several cities on the west coast are between 25 -78 minutes based on the 2004 tsunami simulation. Another research for this location focus on sediment deposits, coastal erosion, and coastal change [9-17]. The west coast area is also included in the area with a high level of tsunami hazard [18]. Research on the potensial earthquake along west of Sumatra subduction zone had been carry out, return period of earthquake surrounding this area are 50 to 200 years with magnitude from $M w 8.0$ to 9.2 [19]. However, research on the potential tsunami hazard in the future for the west coast of Aceh Besar has not been carried out. This research is needed to provide sufficient scientific approaches to mitigate tsunami and minimize the casualty in the future.

This study aims to investigate the tsunami hazard on the west coast of Aceh Besar District. The tsunami hazard determined in this research is height, distance, and area of the tsunami inundation based on three earthquake magnitudes scenarios, i.e., Mw 8.0, 8.5, and 
9.2. The scenario earthquake with $\mathrm{Mw} 9.2$ similar to 2004 andaman tsunami and used to validate the model. The COMCOT (Cornell Multigrid Coupled Tsunami Model) tsunami model was used to obtain the height, area, and distance of the tsunami inundation. Results of this study are expected to be a reference in the preparation of tsunami disaster mitigation for this area.

The research is located on the west coast of Aceh Besar District, as shown in Fig 1. The west coast of Aceh Besar consists of 3 sub-districts, namely Lhoknga, Leupung, and Lhoong. Sloping beaches dominate the beach, and some of them have steep beaches with hills. The Lhoknga area is a sloping area inhabited by many residents, tourist areas, and industry (cement factory). During the 2004 tsunami, most of this area was washed away by the tsunami and many casualties. Leupung and Lhoong are located in the southern part of the Lhoknga area and also densely populated areas. Some of these areas are flat, and the coastline is closed to the hills.

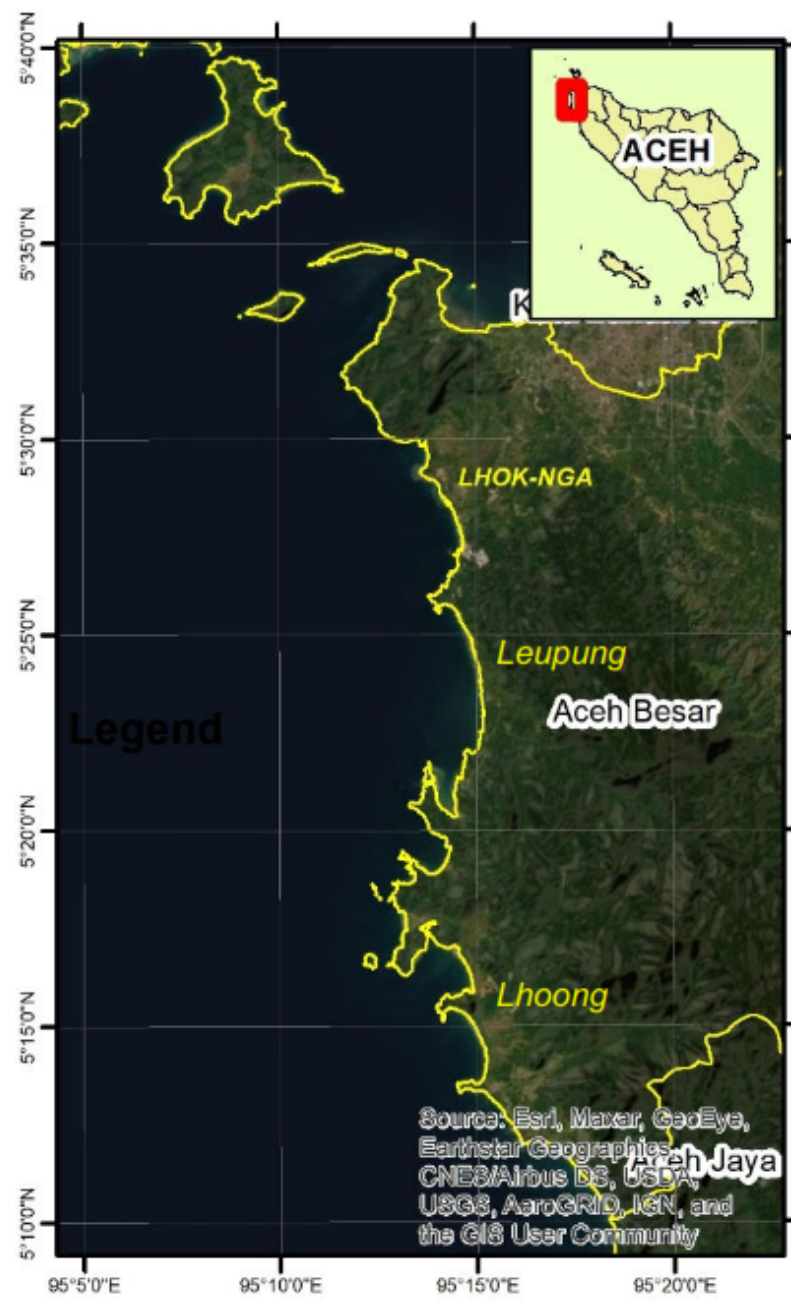

Fig 1. Research location from Google Earth.

\section{Methods}

Tsunami waves may change according to their position from the shoreline and the depth of the water. In deep water, the wave height to length $(\mathrm{H} / \mathrm{L})$ ratio is significant, and in shallow water, the wave height to water depth $(\mathrm{H} / \mathrm{d})$ ratio is relatively high [20]. When a tsunami wave reaches land, the terms used to describe a tsunami wave are flow depth (depth of water), tsunami height (the elevation of water above the reference level), runup height (the maximum elevation the wave reaches at the maximum inundation), inundation distance (maximum horizontal intrusion), and inundation limit (inland limit of wetting) [21,22]. A schematic explanation of the tsunami terms is shown in Fig 2.

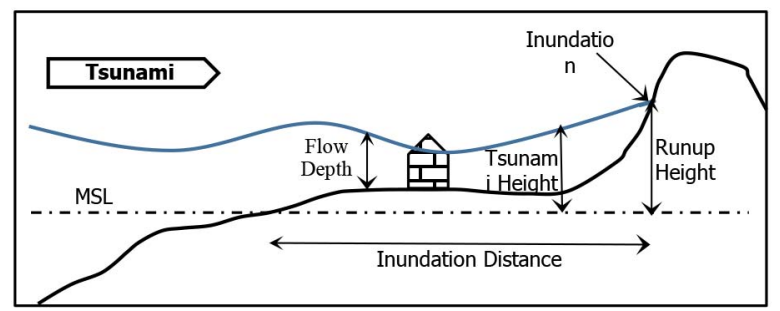

Fig 2. Schematic explanation of some commonly used tsunami terms (refer to IOC UNESCO [23]).

The investigation of tsunami inundation was conducted using numerical simulation using the Cornell Multi-grid Coupled Tsunami model (COMCOT). This numerical model consists of two stages, namely:

1. Tsunami wave generator;

2. Propagation of tsunami waves from the epicenter to the mainland (inundation) using a nested grid system.

The equations used in COMCOT are linear and nonlinear equations of the shallow water equation for both spherical and cartesian coordinate systems [24]. For tsunamis in the deep sea, the height of the tsunami is less than the water depth, so the shallow water linear equation for spherical coordinates was used as follows:

$$
\begin{aligned}
& \frac{\partial \eta}{\partial \mathrm{t}}+\frac{1}{\mathrm{R} \cos \varphi}\left\{\frac{\partial \mathrm{P}}{\partial \psi}+\frac{\partial \eta}{\partial \psi}(\cos \varphi \mathrm{Q})\right\}=0 \\
& \frac{\partial \mathrm{P}}{\partial \mathrm{t}}+\frac{\mathrm{gh}}{\mathrm{R} \cos \varphi} \frac{\partial \mathrm{P}}{\partial \psi}-\mathrm{fQ}=0 \\
& \frac{\partial \mathrm{Q}}{\partial \mathrm{t}}+\frac{\mathrm{gh}}{\mathrm{R}} \frac{\partial \eta}{\partial \psi}+\mathrm{fP}=0 \\
& \mathrm{f}=\Omega \sin \varphi
\end{aligned}
$$

When the tsunami waves reach the coastal area, the equation applied is a non-linear equation. In COMCOT, the shallow water non-linear equation for the spherical coordinate system was used as follows:

$$
\begin{aligned}
& \frac{\partial \eta}{\partial \mathrm{t}}+\frac{1}{\mathrm{R} \cos \varphi}\left\{\frac{\partial \mathrm{P}}{\partial \psi}+\frac{\partial}{\partial \psi}(\cos \varphi \mathrm{Q})\right\}=0 \\
& \frac{\partial \mathrm{P}}{\partial \mathrm{t}}+\frac{1}{\mathrm{R} \cos \varphi} \frac{\partial}{\partial \psi}\left\{\frac{\mathrm{P}^{2}}{\mathrm{H}}\right\}+\frac{1}{\mathrm{R}} \frac{\partial}{\partial \varphi}\left\{\frac{\mathrm{PQ}}{\mathrm{H}}\right\}+\frac{\mathrm{gH}}{\mathrm{R} \cos \varphi} \frac{\partial \eta}{\partial \psi}-\mathrm{fQ}+\mathrm{F}_{\mathrm{x}}=0 \\
& \frac{\partial \mathrm{Q}}{\partial \mathrm{t}}+\frac{1}{\mathrm{R} \cos \varphi} \frac{\partial}{\partial \psi}\left\{\frac{\mathrm{PQ}}{\mathrm{H}}\right\}+\frac{1}{\mathrm{R}} \frac{\partial}{\partial \varphi}\left\{\frac{\mathrm{Q}^{2}}{\mathrm{H}}\right\}+\frac{\mathrm{gH}}{\mathrm{R}} \frac{\partial}{\partial \psi}+\mathrm{fP}+\mathrm{F}_{\mathrm{y}}=0 \\
& \mathrm{~F}_{\mathrm{x}}=\frac{\mathrm{gn}^{2}}{\mathrm{H}^{\frac{7}{3}}} \mathrm{P}\left(\mathrm{P}^{2}+\mathrm{Q}^{2}\right)^{1 / 2} \\
& \mathrm{~F}_{\mathrm{y}}=\frac{\mathrm{gn}^{2}}{\mathrm{H}^{\frac{7}{3}}} \mathrm{Q}\left(\mathrm{P}^{2}+\mathrm{Q}^{2}\right)^{1 / 2}
\end{aligned}
$$

In equations (1)-(7), $\eta$ represents the water surface elevation; $(\mathrm{P}, \mathrm{Q})$ is the volume fluxes in $\mathrm{X}$ (West-East) direction and Y (South-North) direction; $(\varphi, \psi)$ is the latitude and longitude of the Earth; $\mathrm{R}$ is the radius of the Earth; $\mathrm{g}$ is the gravitational acceleration; $\mathrm{h}$ is the water depth. Term $\mathrm{f}$ represents the Coriolis force coefficient due to the rotation of the Earth; $\Omega$ is the rotation rate of the Earth; $\mathrm{H}$ is the total water depth, and $\mathrm{H}=\eta+\mathrm{h}$; $\left(\mathrm{F}_{\mathrm{x}}\right.$, $\mathrm{F}_{\mathrm{y}}$ ) represents the bottom friction in $\mathrm{X}$ and $\mathrm{Y}$ directions; 
$\mathrm{n}$ is the Manning's roughness coefficient, and $\mathrm{g}$ is the gravitational acceleration

The validation was done using the Aida method [25-27]. Validation between observations and computations was carried out using variables tsunami height and inundation distance. The equations used in the Aida coefficient are as follows.

$K_{i}=\frac{x_{i}}{y_{i}}$

$\log K=\frac{1}{\mathrm{n}} \sum_{i=1}^{n} \log K_{i}$

$\log k=\sqrt{\frac{1}{n} \sum_{i=1}^{n}\left(\log K_{i}\right)^{2}-(\log K)^{2}}$

The $K$ and $k$ are Aida coefficient where $K$ represents geometric mean and $k$ represent geometric standard deviation. Variable $x_{i}$ and $y_{i}$ are the observed and computed variables. The results were classified as a good agreement if $0.8 \leq K<1.2$ and $k \leq 1.60$. The smaller the geometric standard deviation $(k)$, the better result.

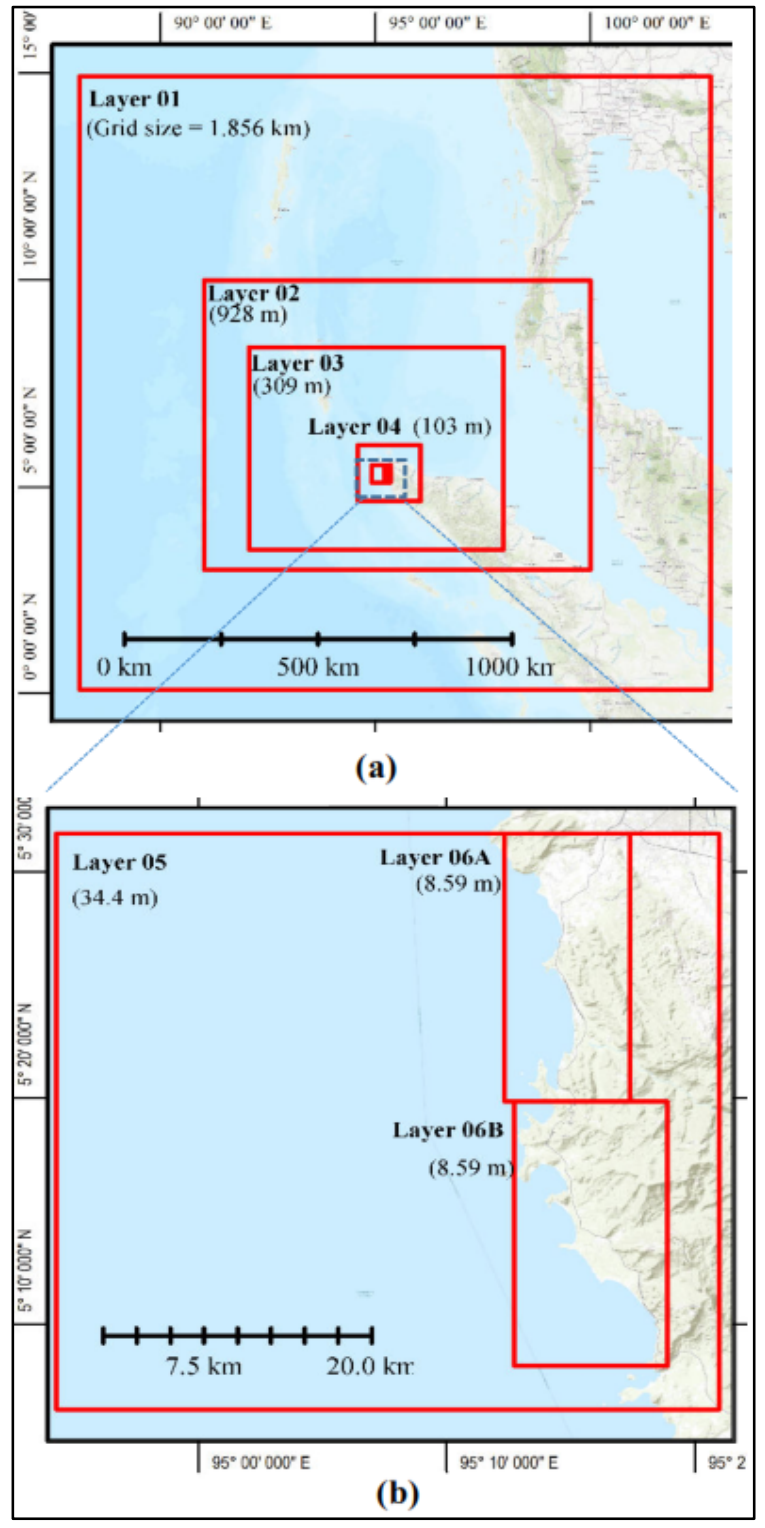

Fig 3. Nested grids for COMCOT model simulation domain: (a) Layers 1-4 and (b) Layer 5, 6A, and 6B

\section{Model Setup}

\subsection{Input Data and Grid Setup}

The numerical simulations were carried out in several stages. The first stage was generating an initial tsunami waveform around the source. In the tsunami wave generator stage, the required input data were bathymetry of the Indian Ocean up to the study area as shown in layer 01 (Fig 3(a)). This data was obtained from GEBCO (General Bathymetric Chart of the Ocean) with a resolution of 1-minute grid size (or 1,856 km) [28]. The source of the wave generator in this model comes from earthquakes based on three earthquake magnitudes scenarios of $-\mathrm{Mw} 8.0,8.5$, and 9.2 in accordance with historical seismic activity for study areas. Earthquake parameters $\mathrm{Mw} 9.2$ are similar to the 2004 tsunami in the Andaman Sea [1].

The second stage in tsunami modeling was the propagation of tsunami waves from the epicenter to the mainland (inundation). More detailed bathymetric, topographic, and land use data (manning values) were required in this stage. Bathymetry data were obtained from BATNAS (National Bathymetry) with a resolution of 6 arc second and DEMNAS (National Digital Elevation Model (DEM) data with a spatial resolution of 0.27 -arcsecond or $8.35 \mathrm{~m}$ which can be accessed through http://tides.big.go.id [29]. Land use data can be accessed through http://appgis.menlhk.go.id/[30]. The land use at the study area consisted of forest/plantation $(\mathrm{n}=0.035)$, housing/build-up area $(\mathrm{n}=0.040)$, open land/rice field $(\mathrm{n}=0.02)$, and ponds $(\mathrm{n}=0.017)$.

Table 1. Rupture parameters.

\begin{tabular}{|c|c|c|c|c|c|c|c|c|c|c|}
\hline \multicolumn{2}{|c|}{ Scenario } & 1 & \multicolumn{2}{|c|}{2} & \multicolumn{6}{|c|}{3} \\
\hline \multicolumn{2}{|c|}{ Mw } & 8.0 & \multicolumn{2}{|c|}{8.5} & \multicolumn{6}{|c|}{9.2} \\
\hline \multicolumn{2}{|c|}{ L (Km) } & 165 & 125 & 180 & $\begin{array}{c}20 \\
0\end{array}$ & $\begin{array}{c}12 \\
5\end{array}$ & $\begin{array}{c}18 \\
0\end{array}$ & $\begin{array}{c}14 \\
5\end{array}$ & $\begin{array}{c}12 \\
5\end{array}$ & $\begin{array}{c}38 \\
0\end{array}$ \\
\hline \multicolumn{2}{|c|}{ W (km) } & 75 & 75 & 75 & $\begin{array}{c}15 \\
0\end{array}$ & $\begin{array}{c}15 \\
0\end{array}$ & $\begin{array}{c}15 \\
0\end{array}$ & $\begin{array}{c}15 \\
0\end{array}$ & $\begin{array}{c}15 \\
0\end{array}$ & $\begin{array}{c}15 \\
0\end{array}$ \\
\hline \multicolumn{2}{|c|}{ Dis (m) } & 8 & 8 & 8 & 14 & 13 & 15 & 7 & 7 & 7 \\
\hline \multicolumn{2}{|c|}{ Strike $\left(^{\circ}\right)$} & 340 & 335 & 340 & $\begin{array}{c}32 \\
3\end{array}$ & $\begin{array}{c}33 \\
5\end{array}$ & $\begin{array}{c}34 \\
0\end{array}$ & $\begin{array}{c}34 \\
0\end{array}$ & $\begin{array}{c}34 \\
5\end{array}$ & 7 \\
\hline \multicolumn{2}{|c|}{ Dip $\left({ }^{\circ}\right)$} & 15 & 15 & 15 & 15 & 15 & 15 & 15 & 15 & 15 \\
\hline \multicolumn{2}{|c|}{ Rake $\left(^{\circ}\right)$} & 90 & 90 & 90 & 90 & 90 & 90 & 90 & 90 & 90 \\
\hline \multirow{2}{*}{ Epicenter } & Long. & 93 & 93 & 93 & 94 & 93 & 93 & 92 & 92 & 92 \\
\hline & lat & 6 & 4 & 6 & 3 & 4 & 6 & 7 & 8 & 11 \\
\hline \multicolumn{2}{|c|}{ Total L (km) } & 165 & \multicolumn{2}{|c|}{305} & \multicolumn{6}{|c|}{1155} \\
\hline \multicolumn{2}{|c|}{ Depth, D (Km) } & 10 & \multicolumn{2}{|c|}{10} & \multicolumn{6}{|c|}{10} \\
\hline
\end{tabular}

The last stage of this modeling was validation. Validation was carried out using the Aida method for tsunami height and inundation distance variables. The observed tsunami height variable was obtained from NOAA [14]. While the data on the inundation limit inundation distance were digitized from aerial photos before the tsunami (June 2004) and after the tsunami (January 2005) [31].

A nested grid scheme was used to simulate the tsunami wave from tsunami sources to the study area. The nested grid is divided into seven layers. A combination of bathymetric and topographic data from 
GEBCO, BATNAS, and DEMNAS was used in the grid. Layer 1 used a larger grid size $(1.856 \mathrm{~km})$ and a smaller grid on layers $6 \mathrm{~A}$ and $6 \mathrm{~B}(8.59 \mathrm{~m})$. The map of the simulation layer is shown in Fig. 3.

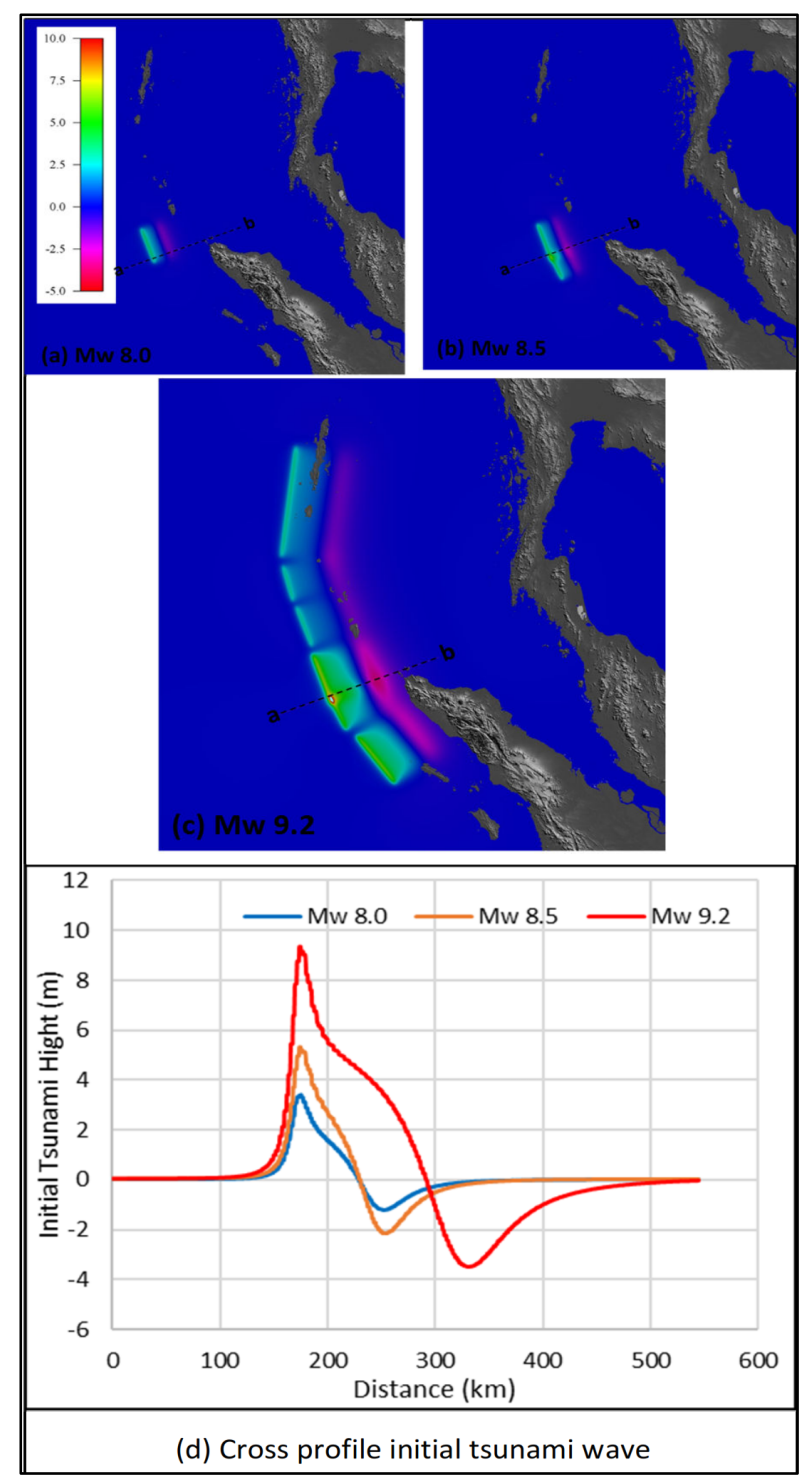

Fig 4. Initial tsunami height with earthquake magnitude $\mathrm{Mw}$ 8.0 (a), Mw 8.5 (b) Mw 9.2(c), and cross profile of initial tsunami wave for different magnitude (d)

\section{Results and Discussion}

\subsection{Initial Condition}

The wave generation was based on three earthquake magnitudes: $\mathrm{Mw}$ 8.0, Mw 8.5, and Mw 9.2. Possibility return period for this earthquake are from 50 to 200 yaers[19]. For scenario Mw 9.2, the rapture parameters were based on the 2004 earthquake conditions [1]. The rupture parameters for $\mathrm{Mw} 8.0$ and $\mathrm{Mw} 8.5$ scenarios were calculated using the scaling law proposed by Wells and Coppersmith [32]. The location of the wave generator was along the Sumatra Andaman subduction zone, and the location of the epicenter was predicted to be at the location of the earthquake in 2004. The rapture parameters for this study are shown in Table 1.
Initial sea survace movement cause by an earthquake is calculated using elastic finite fault plan theory [24]. Initial sea surface movement for the various scenarios is shown in Fig 4. The green color represents positive waves, and the magenta represents negative waves. The initial wave for scenario Mw 8.0 is shown in Fig 4(a). It can be seen that the tsunami generator is a single fault with a maximum wave of $+3.40 \mathrm{~m}$ and a minimum of $-1.21 \mathrm{~m}$. For the scenario of $\mathrm{Mw} 8.5$, the maximum positive and minimum waves are $+5.30 \mathrm{~m}$ and $-2.15 \mathrm{~m}$ with two rupture segments, as shown in Fig 4(b). The highest wave at the epicenter occurs in Mw 9.2 scenario with the maximum positive wave of $+9.378 \mathrm{~m}$ and the minimum wave of $-3.507 \mathrm{~m}$ with six rupture segments (Fig 4(c)). The cross-section profile of tsunami wave shape at the epicenter for all scenarios is shown in Fig 4(d).

\subsection{Validation}

Validation was carried out on the tsunami waves reaching land or inundation. Validation was carried out for the tsunami height and inundation distance variables based on the Mw 9.2 earthquake magnitude scenario (2004 tsunami). There are 172 observation points for the 2004 tsunami height distributed along the west coast of Aceh Besar District conducted by NOAA [14]. The results of tsunami inundation modeling are shown in Fig 8 (a), (b), and (c). From the validation results, using the Aida method, it was found that the results of the tsunami modeling in this study were a good agreement with the observed data with a value of $K=1,139$ and a value of $k=1,585$ (Table 2).

Table 2. Validation of tsunami height and inundation distance.

\begin{tabular}{|c|c|c|c|c|c|}
\hline \multirow{3}{*}{$\begin{array}{c}\begin{array}{c}\text { Aida } \\
\text { Coefficient }\end{array} \\
\begin{array}{c}\text { Geometric } \\
\text { mean (K) }\end{array}\end{array}$} & \multirow{3}{*}{$\begin{array}{c}\begin{array}{c}\text { Required } \\
\text { range }\end{array} \\
\mathrm{K}(0.8 \leq \mathrm{K} \\
\leq 1.2)\end{array}$} & \multicolumn{4}{|c|}{ Result } \\
\hline & & \multicolumn{2}{|c|}{$\begin{array}{l}\text { Tsunami Height } \\
\text { (NOAA) }[14]\end{array}$} & \multicolumn{2}{|c|}{$\begin{array}{c}\text { Inundation } \\
\text { Distance }\end{array}$} \\
\hline & & 1.139 & $\begin{array}{c}\text { Good } \\
\text { Agreement }\end{array}$ & 1.036 & $\begin{array}{c}\text { Good } \\
\text { Agreement }\end{array}$ \\
\hline $\begin{array}{c}\text { Geometric } \\
\text { standard } \\
\text { deviation (k) }\end{array}$ & $k(k \leq 1.6)$ & 1.585 & $\begin{array}{c}\text { Good } \\
\text { Agreement }\end{array}$ & 1.130 & $\begin{array}{c}\text { Good } \\
\text { Agreement }\end{array}$ \\
\hline
\end{tabular}

Validation was also carried out for the variable inundation distance. The inundation limit line was obtained based on the comparison of aerial photos before the tsunami (June 2004) and aerial photos after the tsunami (January 2005), as shown in Fig 5 [31]. The post-tsunami images (Fig 5(b), (c), and (d)) show that the area inundated was characterized by brown land color (dead vegetation). The limit of this inundation area was used in the validation process. In this study, the location of the inundation measurement was determined as many as 30 points located along the coast. This location was used as a measurement point for the inundation distance between the digitized inundation limit from aerial photographs and simulation (Fig 6). The inundation distance varies from $500 \mathrm{~m}$ (Leupung area) to $6000 \mathrm{~m}$ (Lhoknga area) depending on topographical conditions. Using Aida method, validation for inundation distance variable has also a good agreement with $K=1,036$ and $k=1,130$. (Table 2). 


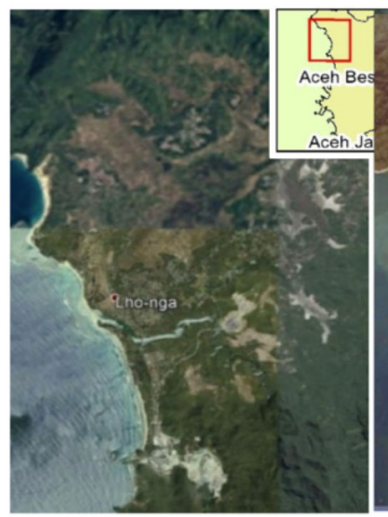

(a)

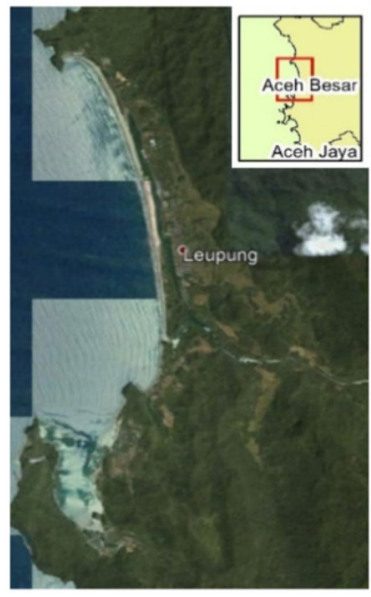

(c)

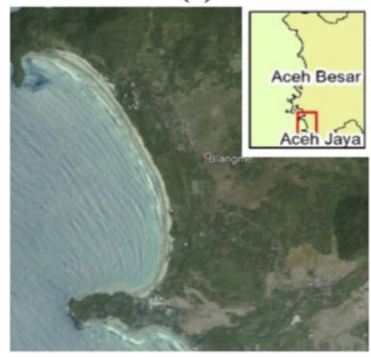

(e)

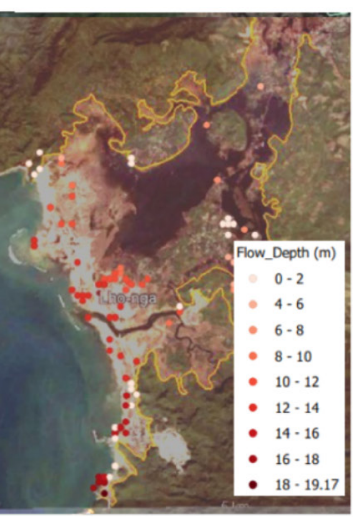

(b)

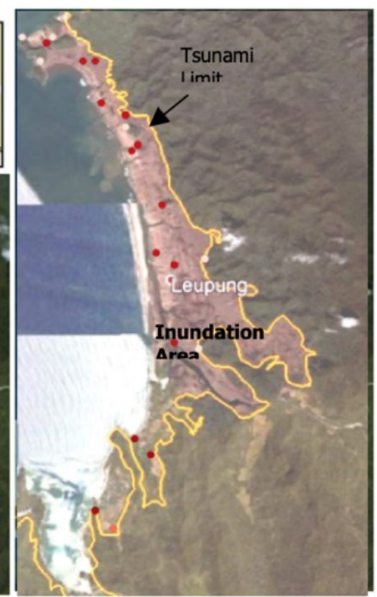

(d)

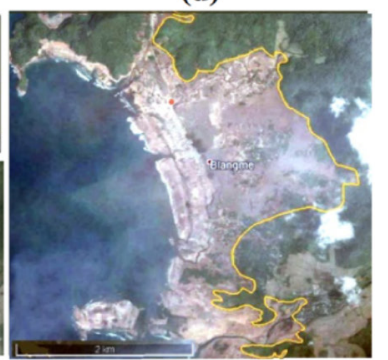

(f)
Fig 5. Satellite images and NOAA Observation point of three main study area locations before (June 2004) and after tsunami 2004 (January 2005) from Google Earth. Images before tsunami for Lho-nga (a), Leupung (c), and Lhoong (e); Images after the tsunami and digitize tsunami limit (orange line) for Lho-nga (b), Leupung (d), and Lhoong (f).

\subsection{Tsunami Height and Inundation Area}

The modeling results for three earthquake scenarios are shown in Fig 8. The image shows the tsunami height distribution (green to red) with a Google Earth map background. The farthest inundation limit and highest tsunami height occurred due to the tsunami with $\mathrm{Mw}$ 9.2, as shown in Fig 8 (a), (c), and (e). Maximum inundation distance occurs in Lhoknga Subdistrict with an inundation distance of $6 \mathrm{~km}$ with a maximum tsunami height of 13 meters. In the Leupung Subdistrict, it can be seen that this area experienced the highest tsunami hit (red color), up to 20 meters, but the inundation distance is not too far because there are hills near the coast.

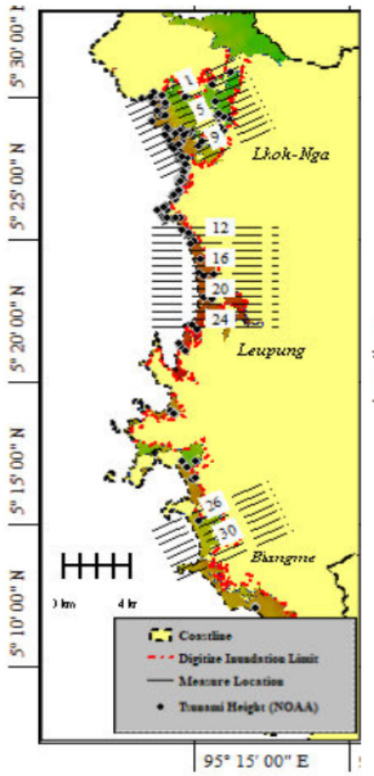

(a)

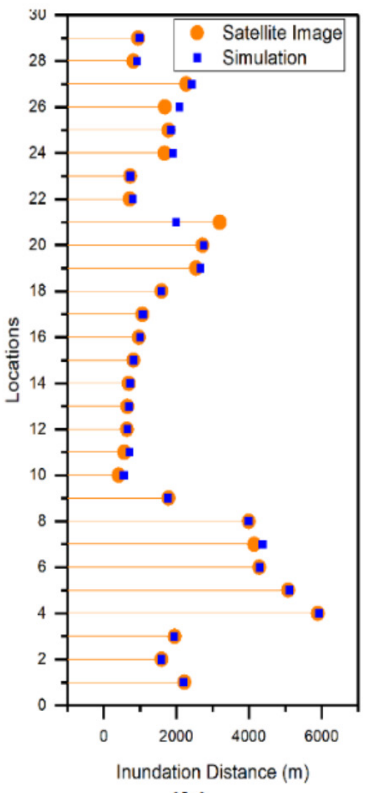

(b)
Fig 6. (a) Locations of measure inundation limit and (b) comparing inundation distance (b) from satellite image after the tsunami and result from COMCOT.

Fig 9 shows a map of the inundation area based on the flow depth categories. The total area of tsunami inundation generated by the $\mathrm{Mw} 9.2$ earthquake is 40.91 $\mathrm{km}^{2}$ or the largest inundation area compared to the other two scenarios. The tsunami inundation area caused by the scenarios $\mathrm{Mw} 8.5$ and $\mathrm{Mw} 8.0$ earthquakes was $15.40 \mathrm{~km}^{2}$ and $5.72 \mathrm{~km}^{2}$. In terms of inundation area, it can be seen that the ratio of the tsunami inundation area with the increase in earthquake magnitude from $\mathrm{Mw}$ 8.0, Mw 8.5 to Mw 9.2 is approximately three times. Fig 7 shows the area of flow depth for the three earthquake scenarios. From the figure, it can be seen that the distribution area for each tsunami flow depth due to $\mathrm{Mw}$ 9.2 is more evenly distributed compared to the distribution area caused by $\mathrm{Mw} 8.5$ and $\mathrm{Mw}$ 8.0. For the Mw 9.2 scenario, the largest area of $\pm 10 \mathrm{~km}^{2}$ occurs at a flow depth of 2-4 m. For the Mw 8.5 and Mw 8.0 scenarios, the largest area occurs at a flow depth of 0-2 meters.

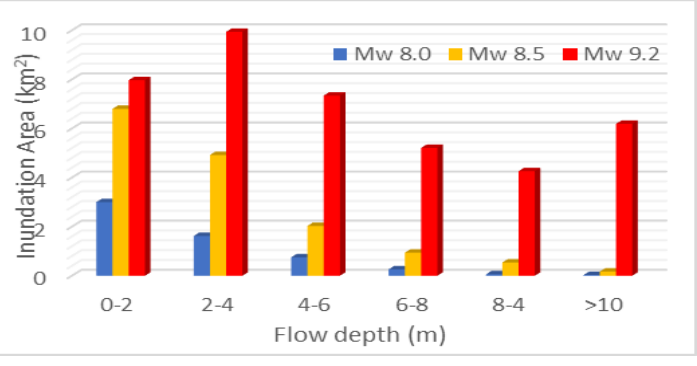

Fig 7. Areas of tsunami inundation with different flow depth and earthquake magnitude 


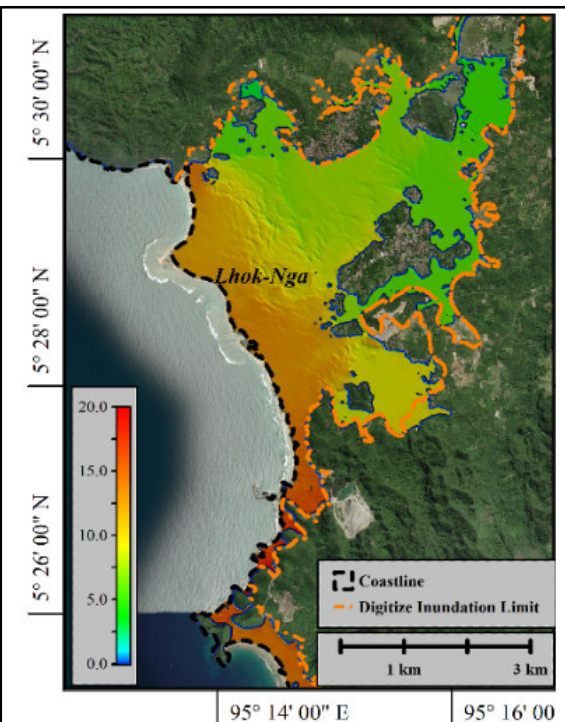

(a) Lhoknga, Mw 9.2

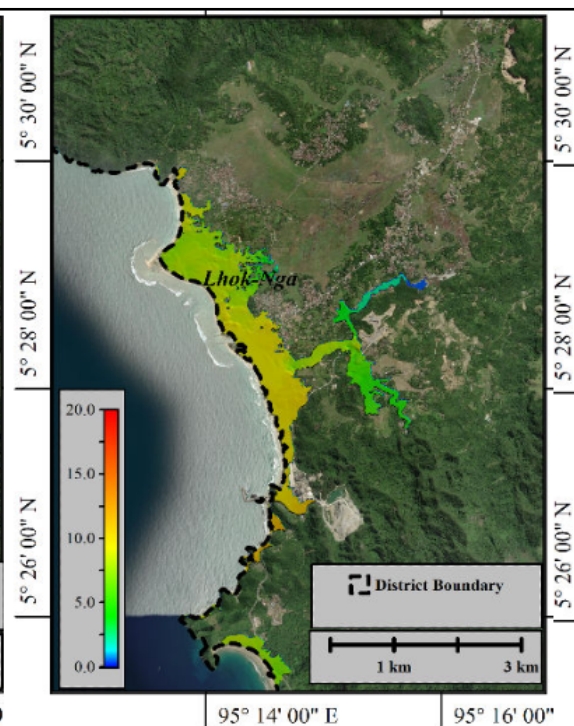

(b) Lhoknga, Mw 8.5

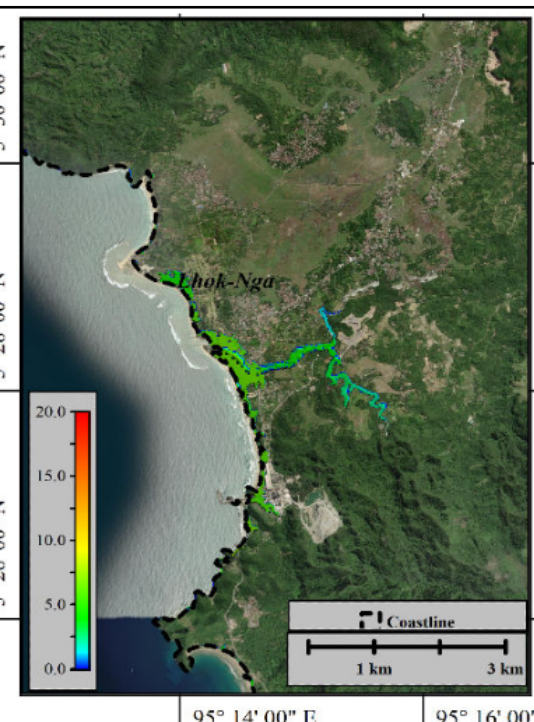

(c) Lhoknga, Mw 8.0

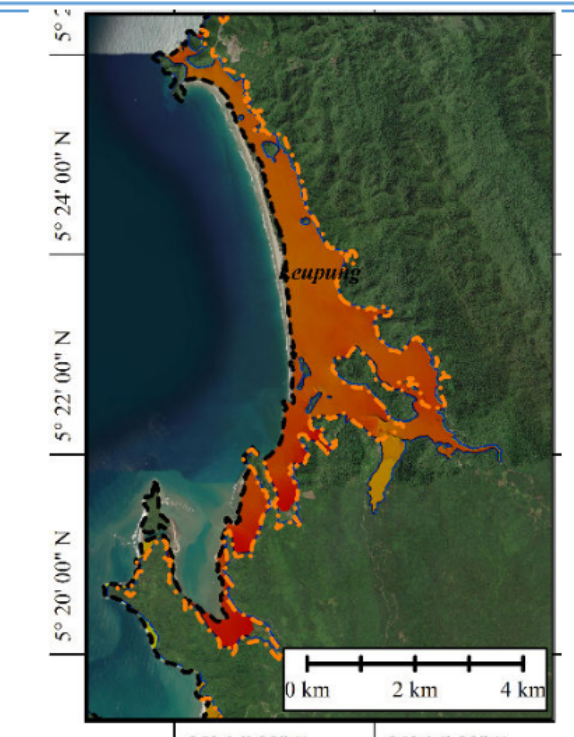

95 14' 00" E

(d) Leupung, Mw 9.2

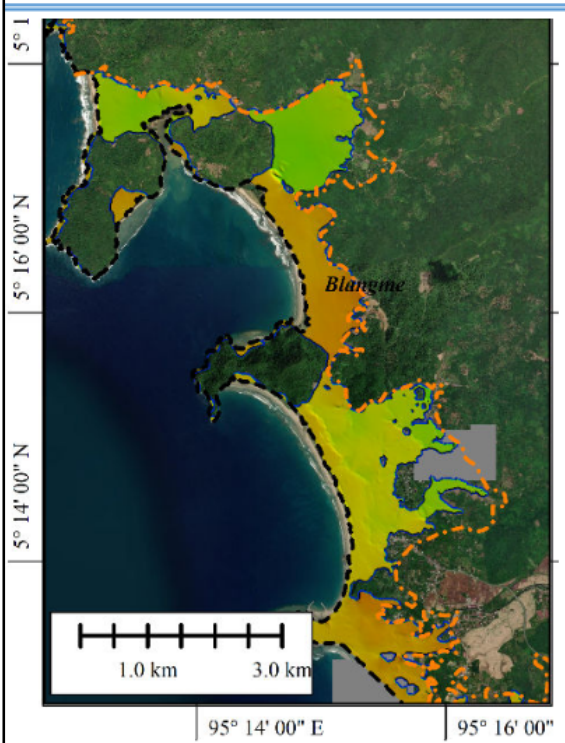

(g) Lhoong, Mw 9.2

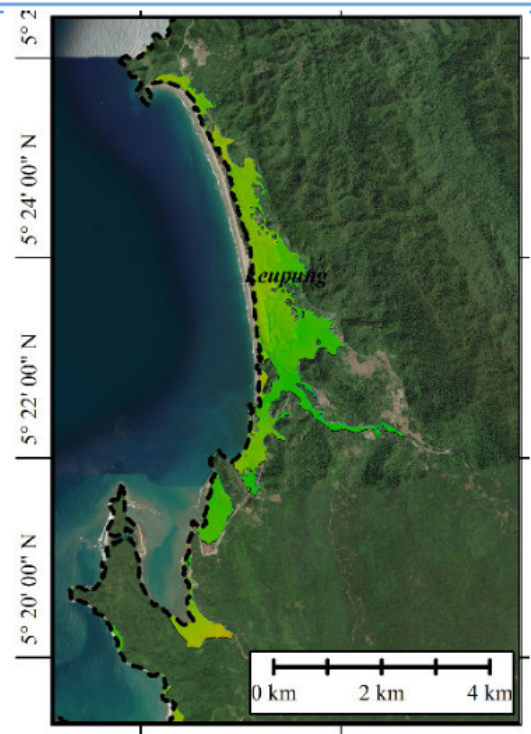

\begin{tabular}{|l|l|l}
\hline $95^{\circ} 14^{\prime} 00^{\prime \prime} \mathrm{E}:$ & $95^{\circ} 16^{\prime} 00^{\prime \prime} \mathrm{B}:$ \\
\hline
\end{tabular}

(e) Leupung, Mw 8.5

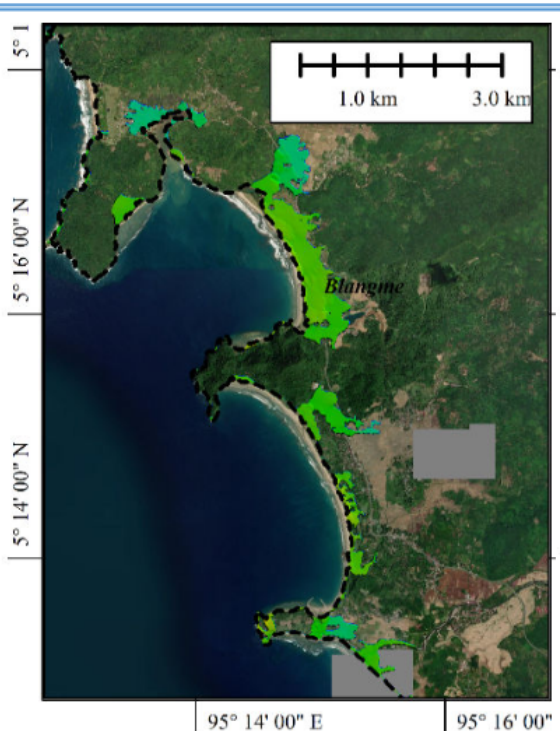

(h) Lhoong, Mw 8.5

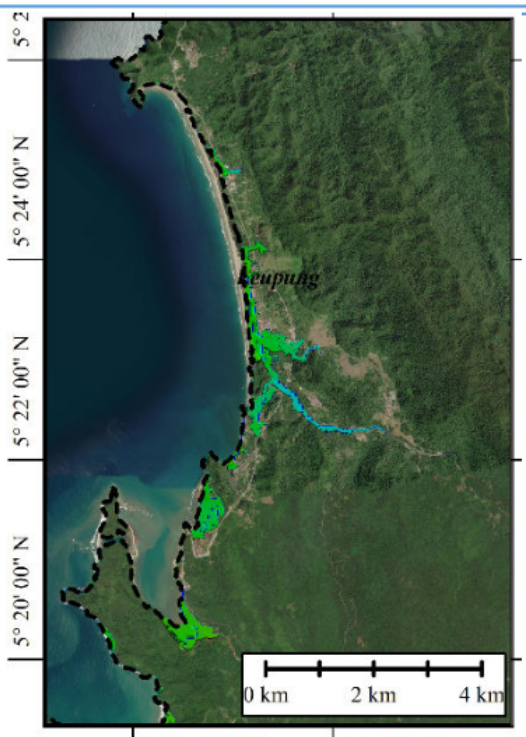

(f) Leupung, Mw 8.0

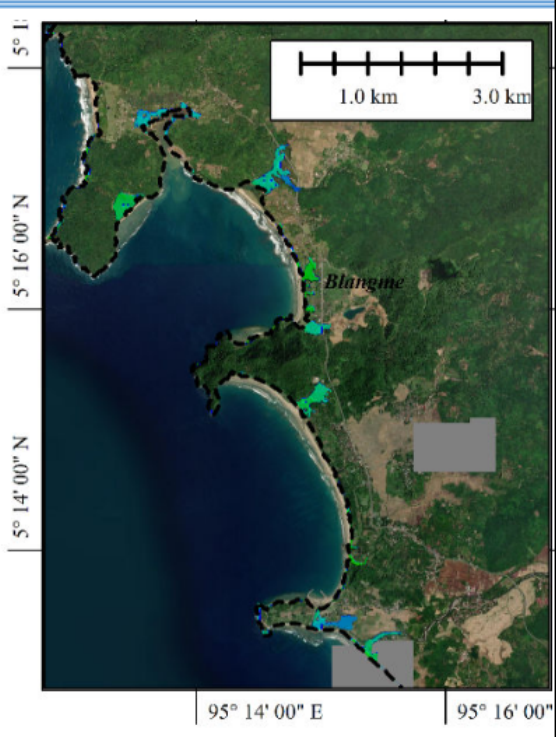

(i) Lhoong, Mw 8.0

Fig 8. Tsunami inundation map for three different earthquake magnitude for three subdistricts overlay with Google Earth image 


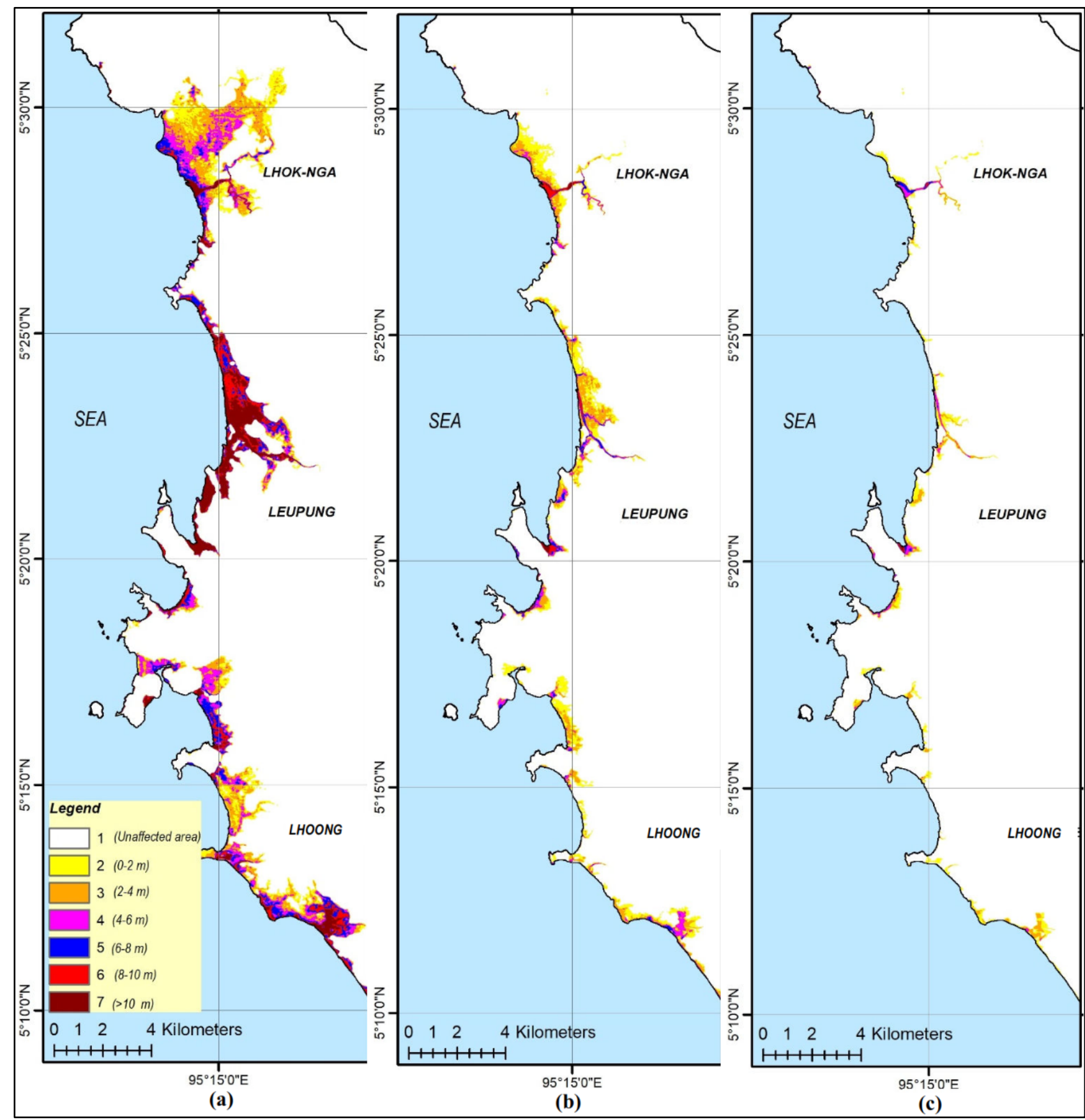

Fig 9. Flow depth and inundation area for scenario earthquake magnitudes-Mw 9.2(a), 8.5 (b), and 8.0 (c)

\section{Conclusion}

The tsunami caused by the earthquake magnitude $\mathrm{Mw}$ 9.2 was found to have the most significant impact on the West coast of Aceh Besar District. From the results of our simulations, this research concludes that:

- The highest tsunami was in the sub-district of Leupung, with a tsunami height up to $20 \mathrm{~m}$.

- The largest inundation distance is in the Lhoknga sub-district, with an inundation distance of $6 \mathrm{~km}$

- The tsunami inundation area reached $40 \mathrm{~km}^{2}$ distributed along the west coast of Aceh Besar District.

With such results, projections of the development of the area should consider historical evidence of tsunami as in the 2004 Indian Ocean tsunami and also smaller intensity tsunamis as revealed in this research.

Acknowledgments. Authors thank to Partnership Enhanced Engagement in Research (PEER) of the United States Agency for International Development (USAID) and NASEM for providing research grant No. 5-395 title: Incorporating climate change induced sea-level rise information into coastal cities' preparedness toward coastal hazards. The grant has enabled authors to collect some data and attend a writeshop to publish this article.

\section{References}

1. S. Koshimura, T. Oie, H. Yanagisawa, and F. 
Imamura, Coast. Eng. J. 51, 243 (2009)

2. A. Muhammad, K. Goda, and N. Alexander, Front. Built Environ. 2, 33 (2016)

3. W. Sengara, H. Latief, and M. S. B. Kusuma, Geomech. Geoengin. An Int. J. 5, 57 (2010)

4. A. Azmeri, C. Mutiawati, N. Al-Huda, and H. Mufiaty, Int. J. Disaster Manag. 1, 35 (2017)

5. Y. Tsuji, Y. Tanioka, H. Matsutomi, Y. Nishimura, T. Kamataki, Y. Murakami, T. Sakakiyama, A. Moore, G. Gelfenbaum, S. Nugroho, B. Waluyo, I. Sukanta, R. Triyono, and Y. Namegaya, J. Disaster Res. 1, 103 (2006)

6. I. Nistor and K. Xie, in Indian Ocean Tsunami, edited by Tad S Murty, U. Aswathanarayana, and N. Nirupama, 1st ed. (CRC Press, London, 2007), pp. 185-208

7. Badan Pusat Statistik (BPS), Kabupaten Aceh Besar Dalam Angka 2019 (Aceh Besar, 2019)

8. Syamsidik, T. M. Rasyif, and S. Kato, Int. J. Disaster Risk Reduct. 14, 403 (2015)

9. L. Li, Q. Qiu, and Z. Huang, Nat. Hazards 64, 1549 (2012)

10. R. Paris, P. Wassmer, J. Sartohadi, F. Lavigne, B. Barthomeuf, E. Desgages, D. Grancher, P. Baumert, F. Vautier, D. Brunstein, and C. Gomez, Geomorphology 104, 59 (2009)

11. B. Ontowirjo, R. Paris, and A. Mano, Nat. Hazards 65, 1967 (2013)

12. K. Satake, Y. Nishimura, P. S. Putra, A. R. Gusman, H. Sunendar, Y. Fujii, Y. Tanioka, H. Latief, and E. Yulianto, Pure Appl. Geophys. 170, 1567 (2013)

13. A. R. Gusman, Y. Tanioka, and T. Takahashi, Earth, Planets Sp. 64, 3 (2012)

14. (n.d.)

15. T. Siregar Novita, Progr. Stud. Kehutan. USU (2016)

16. Syamsidik, M. Al'ala, H. M. Fritz, M. Fahmi, and T. M. Hafli, Nat. Hazards Earth Syst. Sci. 19, 1265 (2019)

17. T. Rasyif, S. Syamsidik, M. Al'ala, and M. Fahmi, J. Coast. Conserv. 20, (2016)

18. N. Horspool, I. Pranantyo, J. Griffin, H. Latief, D. Natawidjaja, W. Kongko, A. Cipta, B. Bustaman, S. Anugrah, and H. Thio, Nat. Hazards Earth Syst. Sci., 14, 3105-3122, 2014 2, (2014)

19. A. Jihad, U. Muksin, Syamsidik, A. Suppasri, M. Ramli, and V. H. Banyunegoro, Int. J. Disaster Risk Reduct. 51, 101800 (2020)

20. E. Bryant, Tsunami: The Underrated Hazard (Third Edition), Third Edit (Springer International Publishing, Kuala Lumpur, 2014)

21. USGS, (n.d.)

22. Intergovernmental Oceanographic Commission, (2019)

23. UNESCO-IOC, 1 (2012)

24. X. Wang, Cornell Univ. 6, 1 (2009)

25. I. AIDA, J. Phys. Earth 26, 57 (1978)

26. Tursina, Syamsidik, S. Kato, and M. Afifuddin, Int. J. Disaster Risk Reduct. 55, 102084 (2021)

27. R. Komata, IOP Conf. Ser. Earth Environ. Sci. 326, (2019)

28. International Hydrographic Organization (IHO) and (IOC) Intergovernmental Oceanographic Commission (IOC), UNESCO (n.d.)

29. Pusat Jaring Kontrol Geodesi dan Geodinamika, (n.d.)

30. Direktorat Jenderal Planologi Kehutanan, (n.d.)

31. Google Earth (n.d. )

32. D. Wells and K. Coppersmith, Bull. Seismol. Soc. Am. 84, 974 (1994) 